\title{
Gairaigo: Japanese EFL Learners' Hidden Vocabulary
}

\section{Brendan Garland}

Asia University

\section{Reference Data}

Garland, B. (2021). Gairaigo: Japanese EFL learners' hidden vocabulary. In P. Clements, R. Derrah, \& P. Ferguson (Eds.), Communities of teachers \& learners. JALT. https://doi.org/10.37546/ JALTPCP2020-24

Japanese is a language that accepts a great number of foreign words (known as gairaigo) into its lexicon, and in modern times these words come predominantly from English. However, into its lexicon, and in modern times these words come predominantly from English. However, latent vocabulary to benefit EFL learners has not been fully realized. This paper describes an exploratory study of a short course given to a university EFL class in Japan, which was intended to explore ways to activate learners' English-gairaigo vocabulary. Students received lessons in recognition of English-based gairaigo, differences between English and gairaigo, and were encouraged to explore their own knowledge and use of gairaigo. Pre and post testing suggested a positive correlation between the course and improvements in some English-gairaigo abilities, and survey results indicated students' enthusiastic response to acquiring a skill they felt was useful in their English studies.

日本語は外来語を大量に受けいれる言語であり、なかでも現代では主に英語由来の語が多い。しかし、何千もの一般的な 英語の単語が基であるにもかかわらず、EFL学生に役立つこの潜在的な語彙に関する積極的な研究と使用は十分に実施され てはいない。本論は日本の大学のEFLクラスを対象に、学生が英語由来の語彙を活性化する方法を探ることを目的とした短期 講座について論究した。学生は、英語由来の外来語を認識し、英語と外来語の違いを見分ける授業を受け、自分自身で外来語 関係があることが示唆され、また調査結果において、英語学習に役立つスキルの習得に対する学生の熱心な反応が示された。

apanese, like English, has long been a language accustomed to borrowing. Its first written form was imported from China in the form of kanji, the Chinese logographic writing system. From kanji, the kana syllabaries of hiragana and katakana were derived in order to both aid in literacy and graft a foreign writing system onto the Japanese language. Over time, these two syllabaries became distinct, with hiragana used mostly with Japanese words for grammatical purposes, and katakana used primarily to represent words of foreign origin which came into the language after the importation of Chinese kanji.

English followed a somewhat similar course, with an imported writing system and a vocabulary significantly augmented by contact with foreign cultures. These two languages would later meet and exchange in a major way, particularly in the latter half of the $20^{\text {th }}$ century.

\section{Gairaigo}

In Japanese, this encounter is codified into the language structure of gairaigo (外来 語), the name for katakana transliterations of foreign words. Though in its early stages gairaigo originated from a number of languages, in the post-war era new gairaigo words have come primarily from English. A 1964 survey by the Japanese Language Research Institute found that about $10 \%$ of words used in everyday Japanese conversation are gairaigo, with $90 \%$ of these coming from English (cited in Loveday, 1986).

In terms of overall proportion of vocabulary, a survey of dictionary word distributions found that in 1891, gairaigo accounted for 551 terms, or $1.4 \%$ of the overall content, and by 1989 this number had increased to 13,300 terms, or $9.95 \%$ of the overall content (Tomoda, 1999, p. 234). These are incredible figures, particularly when taking into account the vast linguistic divide between Japanese and European languages such as English, and the short time frame in which these terms were adopted. According to Japanese loanwords researcher Frank Daulton (2008), "The principal engine of word generation in contemporary Japanese is borrowing from English...today's Japanese are living in the generation of gairaigo, witnessing a revolution of words" (p. 40). Indeed, any casual perusal of a Japanese publication or TV show will inevitably turn up dozens of gairaigo terms, with new words coming into the language almost daily. 
Included among the English-gairaigo terms are many of the most frequently used English words. Daulton $(2008$, p. 83$)$ identified 1,356 word families corresponding to gairaigo loanwords in Nation's (2004) British National Corpus 3000 list, a nearly 50\% coverage, with the highest level of correspondence (54.8\%) occurring at the first 1000 level, which represents the most frequently used words. Running Daulton's terms through a cross-check of the New General Service List (Browne, 2013), created by Browne, Culligan, and Phillips, uncovered a 76\% cumulative coverage of tokens found within the list. There is evidently a high correspondence between words that are deemed crucial for English communication and English-based gairaigo.

\section{Cognates and Language Learning}

And so, with such a vast store of ready-to-use, basic vocabulary at hand, it seems only logical that teachers of English in Japan would draw upon this resource in their classes. Yet herein lies one of the great mysteries of Japanese EFL education: the subject of gairaigo and its connection with English is rarely, if ever, mentioned in most Japanese EFL contexts. According to Daulton, most Japanese teachers of English avoid explicitly teaching about or discussing the topic of gairaigo $(2011$, p. 8). There are a number of reasons for this. From a societal point of view, as Tomoda (2005, para. 8) explains, the “...increase in katakana word has received widespread comment and there have been calls for limits to be placed on the use of these words." Indeed, an editorial from The Japan Times decries that "the torrential influx of foreign words into the Japanese language...has happened at such a rate that many Japanese are now unable to fully understand each other" (Otake, 2007, para. 2). In research circles as well, gairaigo is often disparaged; according to Hardgave (2005), a number of researchers, "view gairaigo as a hindrance in their TEFL efforts" (p. 153). All of this of course has an effect on classrooms, in which, as mentioned, the subject of gairaigo is rarely dealt with, and on rare occasions when it is mentioned, it is often only to warn students of its potential problems (see Daulton, 2011).

Despite this, research into cognates and second language acquisition has consistently shown them to be of tremendous benefit to learners of a variety of second languages (Hancin-Bhatt \& Nagy, 1994; Ringbom, 2007; White \& Horst, 2012), including Japanese learners of English (Allen, 2018; Uchida, 2001). Nation, in his psycholinguistic explanation of aspects of word knowledge, states that "Words which have a similar form to first language words will have a lighter learning burden than words containing unfamiliar sounds and unfamiliar combinations of sounds." (2013, p. 70). A word like party therefore, with its phonologically similar gairaigo equivalent paatii, should be much easier for students to grasp than words like thigh or shrub which have no gairaigo counterpart. Thus, contrary to the current state of affairs, teachers having foreknowledge of English-gairaigo terms and including them in class could present an advantage to EFL students in Japan, as Stubbe, Hoke, and O'Sullivan (2013) have noted.

The following exploratory research project was designed to explore the explicit instruction of English-gairaigo, and its potential effect on students' vocabulary abilities and their motivation for further English-gairaigo study.

\section{Research Questions}

The research questions for this project were as follows:

RQ1. What effect does studying gairaigo have upon students' vocabulary comprehension, particularly in relation to English-based gairaigo words not taught in the classroom?

RQ2. Are students interested in the subject of gairaigo, and do they feel motivated to study it?

\section{Method}

For this project, a brief course was developed to promote students' awareness of the gairaigo and English connection, and their facility in using this connection to help expand their vocabulary base and abilities; pre and post testing was conducted to determine what, if any, effect the course had on students' vocabulary abilities pertaining to English-gairaigo words, including recognition of these words and knowledge of their formal and structural similarities and differences with English; and a survey was conducted in class to determine student interest in the subject.

\section{Participants}

The study was conducted with a first-year English class at a Japanese university. The class consisted of 16 students majoring in Economics, all of lower intermediate English ability, with a CEF level ranging from A2 to B1. The class met four times a week, for 45 minutes. Thirteen of the students took part in the survey after the course. All the participants gave informed, written consent, and the project was cleared with the university's institutional review board. In addition, all participants were informed that they would remain anonymous throughout the research process, and that their responses would not influence their course grade. 


\section{The Gairaigo Course}

The class went through a week-long course of four 45-minutes lessons on the subject of gairaigo. The lessons were designed to raise students' awareness of English-based gairaigo, to familiarize them with common errors associated with moving between gairaigo and English, and to encourage interest in the subject. Using Daulton's highly informative book Japan's Built-in Lexicon of English-based Loanwords (2008) as a

framework, main areas of instruction were selected. These included teaching students the common errors mentioned above, as well as strategies for using gairaigo headwords to expand English vocabulary (for example by using the English-gairaigo headword ansaa to create the forms answering and answered).

\section{Day 1}

On the first day, in addition to introducing the topic of gairaigo, students were taught about shortening, the Japanese tendency to abbreviate many gairaigo words to their shortest comprehensible form (e.g. paso-kon in place of personal computer). According to Daulton (2008), “...shortening simplifies the pronunciation of loanwords and facilitates their integration into Japanese” (p. 18). Yet this same ease of use in Japanese can lead to confusion or even incomprehension if employed in English, hence the need to address the issue. Following instruction, students were given a worksheet to do in class (see Appendix A), in which they were asked to circle shortened gairaigo (referred to as minigairaigo on the worksheet), after which they were enjoined by the teacher to write in the full English equivalent. Finally, students engaged in conversation practice which involved using shortened gairaigo in a comprehensible English form and were given homework on the day's topic.

\section{Day 2}

On day two, students were taught about the semantic change and shift that frequently occurs when words are taken from English and transformed into gairaigo. As Daulton (2008) writes, "English words inevitably acquire...meanings culture-specific to Japan" (p. 20). Hence aisu (ice) refers to ice cream, meeru (mail) refers to email, and the peculiar beebii-kaa (baby car) means stroller. Students were also taught about the related topic of grammatical transformation between English and gairaigo; for example, the necessity, when communicating in English, of omitting the final 's' in 'shoes' when referring to a singular subject, as opposed to the gairaigo word shuuzu (shoes) which, in keeping with Japanese grammar, does not change according to whether a subject is singular or plural.
In order to introduce and explain the topic to students, a slideshow was created, including pictures of common gairaigo false cognates alongside their English equivalents (see Appendix B). After instruction, students were once again asked to do worksheets, participated in conversation practice using gairaigo words with semantic change and grammatical transformation in English, and were given a homework assignment dealing with the day's topics.

\section{Day 3}

During day three of the course, students were introduced to the idea of using gairaigo headwords, and the prefixes and suffixes associated with them, to expand their English vocabulary. Starting with homework examples of gairaigo words brought in by students, some of the most common English prefixes and suffixes were taught. As an example, the word shokku (shock) brought in by a student was used as a headword to create the words shocking and shocked. After, students were given a worksheet (See Appendix C) in which they needed to transform a gairaigo word into English, and then add appropriate suffixes and prefixes to form new words. The gairaigo words used on the worksheet were all taken from the first 1000 of the list of common loanwords corresponding to the BNC (Nation, 2004), found in the appendix to Daulton's book (2008, pp. 133-156). Students also took part in several class games related to the day's topic. As homework, students were asked to write answers to the following questions: "Do you often use gairaigo when you speak Japanese? Why or why not? What is your favorite gairaigo word?" This was in keeping with one of the stated objectives of the course, to raise students' awareness of English based gairaigo. Although given the earlier mentioned frequency of gairaigo within Japanese communication, it is unlikely that students would reply they rarely or never use gairago (though cases of this have been noted; see Daulton, 2011), the question was nevertheless intended to make students consciously reflect upon this usage.

\section{Day 4}

The final day of the course began with students sharing their homework writing in groups (sample response: "Yes I do, because it is natural for me and easy to use. I like donmai"). Students then took part in a series of games intended to help them review what they had learned about gairaigo during the week. Finally, students were thanked for their participation in the course.

As a note, throughout the course, efforts were made to simplify linguistic terminology for students in a way that would make it both comprehensible and practical. As an 
example, shortened and back-clipped words were referred to as "mini-garaigo," while headwords and the prefixes and suffixes associated with them were known collectively as the "word family."

\section{Testing}

Pre and post tests, each with differing test items, were given to students in the class. The pre test was given in the lesson preceding the gairaigo course, and the post test was given in the lesson immediately after the completion of the course. The test was divided into three different sections, with each section designed to test a different Englishgairaigo related skill. Specifically, the test was designed to ascertain if students could apply the general principles they learned about English-gairaigo words during the course onto unfamiliar terms not covered during the course.

Section one of the test contained questions to test students' ability to recognize shortened and back-clipped gairaigo; an example of this encountered during the class was the gairaigo term basuke (short for basketball), and an example from the test was the word grotesque (shortened to guro in gairaigo), a word not taught during the course. Section two contained questions intended to test students' ability to form new word forms based on gairaigo headwords; in class this included the headword-derived term answering, from the gairaigo base word ansaa, and on the test the word renter, from the gairaigo base rento. Finally, section three included questions intended to test students' ability to recognize semantic change and false cognates; an in-class example of this was the word cunning (kanningu) which has the meaning of cheating in gairaigo, and from the test the phrase one piece (wanpiisu) which is used in gairaigo to refer to a dress. Each section of the test also contained a number of distractor questions, unrelated to the topic of gairaigo, in order to avoid students guessing the subject of the test (though admittedly this may have been less effective on the test taken after the course). This was deemed necessary in order to get a more accurate representation of how well students recognized and used English-based gairaigo under normal conditions. Likewise, the title of the test was kept general, and students were not informed of the specific skills they were being tested on.

The first two sections of the test were graded using a simple correct/incorrect criteria with correct answers receiving a score of one and incorrect answers a score of zero. The third section of the test however had a sliding scale applied. This was done to determine whether students showed progress in their comprehension, moving from the Japanese false cognate definition of the word (with a corresponding score of 1), to either a more neutral definition (score of 2) or the correct definition (score of 3). As an example, on the test students were given the word front, which has the false cognate furonto in gairaigo, along with three possible definitions $A, B$ and $C$, and then asked to choose the correct English definition. If the students chose $A$ hotel reception (in gairaigo the term furonto has this linguistically narrowed sense), they received a score of 1 . If they chose the more neutral answer $B$ to move up, they received a 2 , and if they chose the correct answer $C$ the most forward part, they received a 3.

Many of the items on the test were taken from the first 1000 of the list of common loanwords corresponding to the BNC (Nation, 2004), found in the appendix to Daulton's book (2008, pp. 133-156), as this was determined to be the level best corresponding to students' English abilities. An exception to this were the semantically shifted gairaigo and false cognate forms included in the test which, due to their limited and rather idiosyncratic nature, could not be correlated with any existing vocabulary lists. An example of this taken from the test is the term high tension, which in the English sense of electricity represents a rather technical, advanced level of vocabulary, whereas the gairaigo word tenshon is used to refer to a high level of excitement and is much more common.

Care was also taken to avoid terms from the first test appearing on the second, as well as to avoid too many terms taught during the gairaigo course appearing on the second test (which could result in simply testing students' retention of words from the course, rather than if they had gained new skill sets relating to gairaigo).

\section{Survey}

Students were given a Likert scale survey of five statements, in English with Japanese translations, and asked to indicate their level of agreement with each, in order to ascertain their interest in the subject of gairaigo, and how useful they felt its study could be in improving their English skills. One statement included a reversed pair (a positive and negative statement on the same subject) in order to check for reliability of responses (Paulhus, 1991). A free response section was included for any further student comments.

\section{Results}

Comparing pre and post test results for the class, the overall mean score improved by 4.5 points, or $9 \%$ (M: 29.9, SD: 2.1 to M: 34.4, SD: 4.6), indicating a statistically significant result under a paired samples $\mathrm{T}$ test $(\mathrm{p}<.05)$. This is sufficient evidence to reject the null hypothesis for this experiment, in this case being that test scores would show no change after the intervention of the gairaigo course. 
Upon closer examination however, we can see that this was due to a significant increase in scores on the third section of the test, which dealt with false cognates and semantic change between gairaigo and English. Looking at sections 1 and 2, we can see that the mean of student scores actually decreased slightly (see Table 1).

Table 1

Pre and Post-Gairaigo Course Test Results

\begin{tabular}{lll} 
Sections & $\begin{array}{c}\text { Pre-Test Mean and Standard } \\
\text { Deviation }\end{array}$ & $\begin{array}{c}\text { Post-Test Mean / Standard } \\
\text { Deviation }\end{array}$ \\
\hline Section 1 & M: 6.9 (out of 10 possible) & M: 6.7 (out of 10 possible) \\
(shortened gairaigo) & SD: 1.2 & SD: 1.9 \\
Section 2 & M: 7 (out of 10 possible) & M: 5.8 (out of 10 possible) \\
(gairaigo headwords) & SD: 1.4 & SD: 1.5 \\
Section 3 & M: 16 (out of 30 possible) & M: 21.9 (out of 30 possible) \\
$\begin{array}{l}\text { (gairaigo semantic } \\
\text { change/false cognates) }\end{array}$ & SD: 1.5 & SD: 3.2 \\
Overall & M: 29.9 (out of 50 possible) & M: 34.4 \\
& SD: 2.1 & SD: 4.6 \\
\hline
\end{tabular}

Turning to the results of the class survey, we notice a decidedly positive response from students towards the study of gairaigo, with 9 out of 13 respondents indicating that they either agreed or strongly agreed with the statement "I enjoy learning about gairaigo" (see Table 2). At the same time, no students replied that they strongly agreed with statement 4 , the same statement in reverse.

Interestingly, students indicated even more strongly that they believed the study of gairaigo improved their English, with 6 of the respondents strongly agreeing with the second statement, and another 3 agreeing. There would seem to be a "good for me" effect at play here whereby some students, regardless of their enthusiasm for studying gairaigo, nevertheless believe it is useful for improving their language skills.

Statement 3, "The worksheets and powerpoints on gairaigo were helpful and enjoyable," received the most positive responses of all, with 10 respondents selecting either strong agreement or agreement, indicating that students appreciated the materials that were prepared for the class,

Finally, we can discern a positive outlook towards further gairaigo study in the responses to the fifth statement. Over $50 \%$ of respondents agreed or strongly agreed with the statement "I would like to learn more about gairaigo" This could bode well for a potentially longer course on the subject, or more regular inclusion of gairaigo in curriculums.

Table 2

Post-Gairaigo Course Test Results

\begin{tabular}{|c|c|c|c|c|c|}
\hline Statement & $\begin{array}{l}\text { Strongly } \\
\text { Agree }\end{array}$ & Agree & $\begin{array}{l}\text { Neither } \\
\text { or N/A }\end{array}$ & Disagree & $\begin{array}{l}\text { Strongly } \\
\text { Disagree }\end{array}$ \\
\hline $\begin{array}{l}\text { 1. I enjoy learning about gairaigo. } \\
\text { 私は、外来語を学ぶのが楽しいです。 }\end{array}$ & 1 & 8 & 4 & 0 & 0 \\
\hline $\begin{array}{l}\text { 2. Learning about gairaigo helps } \\
\text { me improve my English. }\end{array}$ & 6 & 3 & 4 & 0 & 0 \\
\hline \multicolumn{6}{|l|}{$\begin{array}{l}\text { 外来語を学ぶことは、私の英語力向 } \\
\text { 上の助けになります。 }\end{array}$} \\
\hline $\begin{array}{l}\text { 3. The worksheets and } \\
\text { powerpoints on gairaigo were } \\
\text { helpful and enjoyable. }\end{array}$ & 3 & 7 & 3 & 0 & 0 \\
\hline \multicolumn{6}{|l|}{$\begin{array}{l}\text { 外来語のワークシートとパワーポイン } \\
\text { トは、役に立つたし、楽しかったです。 }\end{array}$} \\
\hline $\begin{array}{l}\text { 4. Learning about gairaigo is not } \\
\text { interesting. }\end{array}$ & 0 & 2 & 5 & 5 & 1 \\
\hline \multicolumn{6}{|l|}{$\begin{array}{l}\text { 私は、外来語を学ぶのが楽しくない } \\
\text { です }\end{array}$} \\
\hline $\begin{array}{l}\text { 5. I would like to learn more } \\
\text { about gairaigo. }\end{array}$ & 1 & 6 & 6 & 0 & 0 \\
\hline 私はもつと外来語を学びたいです。 & & & & & \\
\hline
\end{tabular}


JALT2020

COMMUNITIES OF
TEACHERS \& LEARNERS

\section{Discussion}

In responding to the first research question posed for this project, it would appear that the study of English-based gairaigo has a significant effect on students' vocabulary abilities related to semantically shifted and false cognate gairaigo, though the same cannot be said about the ability to recognize shortened and back-clipped gairaigo, or to form new word forms based on gairaigo headwords. It was interesting to note that progress in recognizing semantically shifted and false cognate gairaigo accounted for the overall improvement in student test scores. In fact, when comparing individual student scores between the two tests, it was found that every student improved in this area, often quite dramatically. These results are particularly noteworthy because, as was previously stated, terms on this portion of the test were not all taken from the first 1000 of the list of common loanwords corresponding to the BNC (Nation, 2004), found in the appendix to Daulton's book (2008, pp. 133-156), and therefore often represented a more advanced level of vocabulary than terms found in the first 1000 of the BNC.

One possible explanation for this result is that recognizing semantic change and false cognates were the easiest skill sets for students to grasp, especially within the limited time frame of the course. This may suggest a relatively quick and effective method of instruction for teachers. Further research in this area could help to verify this.

Conversely, the slightly lower scores in sections 1 and 2 on the second test may indicate that these skills take longer to acquire, demanding more detailed instruction within the framework of a longer course. Moreover, it could be argued that the ability to form words with affixes is a skill set quite distinct from English-gairaigo recognition.

Finally, in regard to the second research question, results from the survey seem to indicate that students are both interested in gairaigo and motivated to study it. As noted students seemed to feel particularly strongly that the study of English-based gairaigo benefited their overall English ability. Many students also expressed interest in continued study of the subject, beyond the confines of a week-long course.

\section{Conclusion}

Gairaigo plays a substantial role in Japanese communication and shows no signs of going away anytime soon. On the contrary, the pace of English loanword growth in Japanese seems to be accelerating, as is demonstrated by the recent influx of pandemicrelated vocabulary. Words like cluster and lockdown, previously unknown to all but the most diligent student of English, are now commonplace.
As this study has sought to demonstrate, the explosion in English-based gairaigo can positively contribute to the classroom. Though as an exploratory study this research was admittedly limited in both size (16 participants, 13 survey respondents) and scope (a week-long course, with all participants taken from the same major at the same institution), it nevertheless led to some promising results. Though the survey given after the course was also limited in size (5 questions, with only one reversed pair), the strength of the responses may suggest that, for students, the inclusion of gairaigo in the class represents an interesting and useful technique to increase English vocabulary. For teachers as well, gairaigo could help to make classes more dynamic by connecting lessons to the evolution of language happening throughout Japan.

This study did not touch upon the issues of pronunciation and oral communication in regard to English-based gairaigo, though as these are a major focus of contemporary Japanese EFL instruction, they could provide a promising avenue for future research. In addition, delayed testing was not carried out, which might have helped to determine any potential long-term retention and benefits of studying gairaigo, and this represents one further possibility for future research.

English-based gairaigo is one of the primary ways Japanese students encounter English outside of class, and given current trends (Daulton, 2008; Tomoda, 2005), its use is likely to become more prominent in the years to come. It is time that English courses in Japan both reflect and benefit from this.

\section{Bio Data}

Brendan Garland teaches in the Center for English Language Education at Asia University, Tokyo. His research interests include classroom group dynamics, loanwords, and learner motivation. <bgarland@asia-u.ac.jp>

\section{References}

Allen, D. (2018). The prevalence and frequency of Japanese-English cognates: Recommendations for future research in applied linguistics. International Review of Applied Linguistics in Language Teaching, 57(3), 355-376. https://doi.org/10.1515/iral-2017-0028

Browne, C. (2013). The New General Service List: Celebrating 60 years of vocabulary learning. The Language Teacher, 37(4), 13-16. Retrieved from https://jalt-publications.org/files/pdfarticle/37.4tlt_featureds.pdf

Daulton, F. E. (2008). Japan's built-in lexicon of English-based loanwords. Multilingual Matters. 
Daulton, F. E. (2011). On the origins of gairaigo bias: English learners' attitudes towards Englishbased loanwords in Japan. The Language Teacher, 35(6), 7-12. Retrieved from https://jaltpublications.org/files/pdf-article/35.6_art1.pdf

Hancin-Bhatt, B., \& Nagy, W. (1994). Lexical transfer and second language morphological development. Applied Psycholinguistics, 15(3), 289-310. https://doi.org/10.1017/ s0142716400065905

Hardgrave, B. (2005). Loanwords--A bridge between Japanese and English? Implications for EFL education in Japan. Thought Currents in English Literature, 78, 143-165.

Loveday, L. (1986). Japanese sociolinguistics: An introductory survey. Journal of Pragmatics, 10(3), 287-326. https://doi.org/10.1016/0378-2166(86)90004-4

Nation, I. S. P. (2004). A study of the most frequent word families in the British National

Corpus. In P. Bogaards and B. Laufer (Eds.), Vocabulary in a second language: Selection, acquisition and testing (pp. 3-13). John Benjamins.

Nation, I. S. P. (2013). Learning vocabulary in another language (2nd ed.). Cambridge University Press.

Otake, T. (2007, September 23). Japanese: A language in a state of flux: "Torrential" import of foreign words threatens the basis of communication. The Japan Times. Retrieved from https:// www.japantimes.co.jp/life/2007/09/23/general/japanese-a-language-in-a-state-of-flux/

Paulhus, D. L. (1991). Measurement and control of response bias. In J. P. Robinson, P. R. Shaver \& L. S. Wrightsman (Eds.), Measures of personality and social psychological attitudes (pp. 17-59). Academic Press.

Ringbom, H. (2007). Cross-linguistic similarity in foreign language learning. Multilingual Matters. Stubbe, R., Hoke, S., \& O'Sullivan, C. (2013). University student knowledge of loanwords versus nonloanwords. In N. Sonda \& A. Krause (Eds.), JALT2012 Conference Proceedings. JALT. Retrieved from https://jalt-publications.org/files/pdf-article/jalt2012-71.pdf

Tomoda, T. (1999). The impact of loan-words on modern Japanese. Japan Forum, 11(1), 231-253. https://doi.org/10.1080/09555809908721634

Tomoda, T. (2005). Change in script usage in Japanese: A longitudinal study of Japanese government white papers on labor. Electronic Journal of Contemporary Japanese Studies. Retrieved from https://japanesestudies.org.uk/articles/2005/Tomoda.html>.

Uchida, E. (2001). The use of cognate inferencing strategies by Japanese learners of English [Doctora dissertation, University of Essex]. Available from https://www.researchgate.net

White, J. L. \& Horst, M. (2012). Cognate awareness-raising in late childhood: Teachable and useful. Language Awareness, 21(1-2),181-196. https://doi.org/10.1080/09658416.2011.639885

\section{Shortened Gairaigo Worksheet}

\section{Appendix A}

\section{Worksheet 1}

Some of these words are mini (shortened) versions of English words. Which ones? Circle all the mini Gairaigo words.

バリアフリー

リアル

トレパン

バスケ

クリエート

パート

スイミング

スマオ

リピート

パワハラ
タバコ

ビル

スピーク

パーティー・ピー

コンバイン

エアライン

アメフ

ポケモン

シャツ

マイクロバス 


\section{JALT2020}

TEACHERS \& LEARNERS

\section{Example False Cognate Slide}

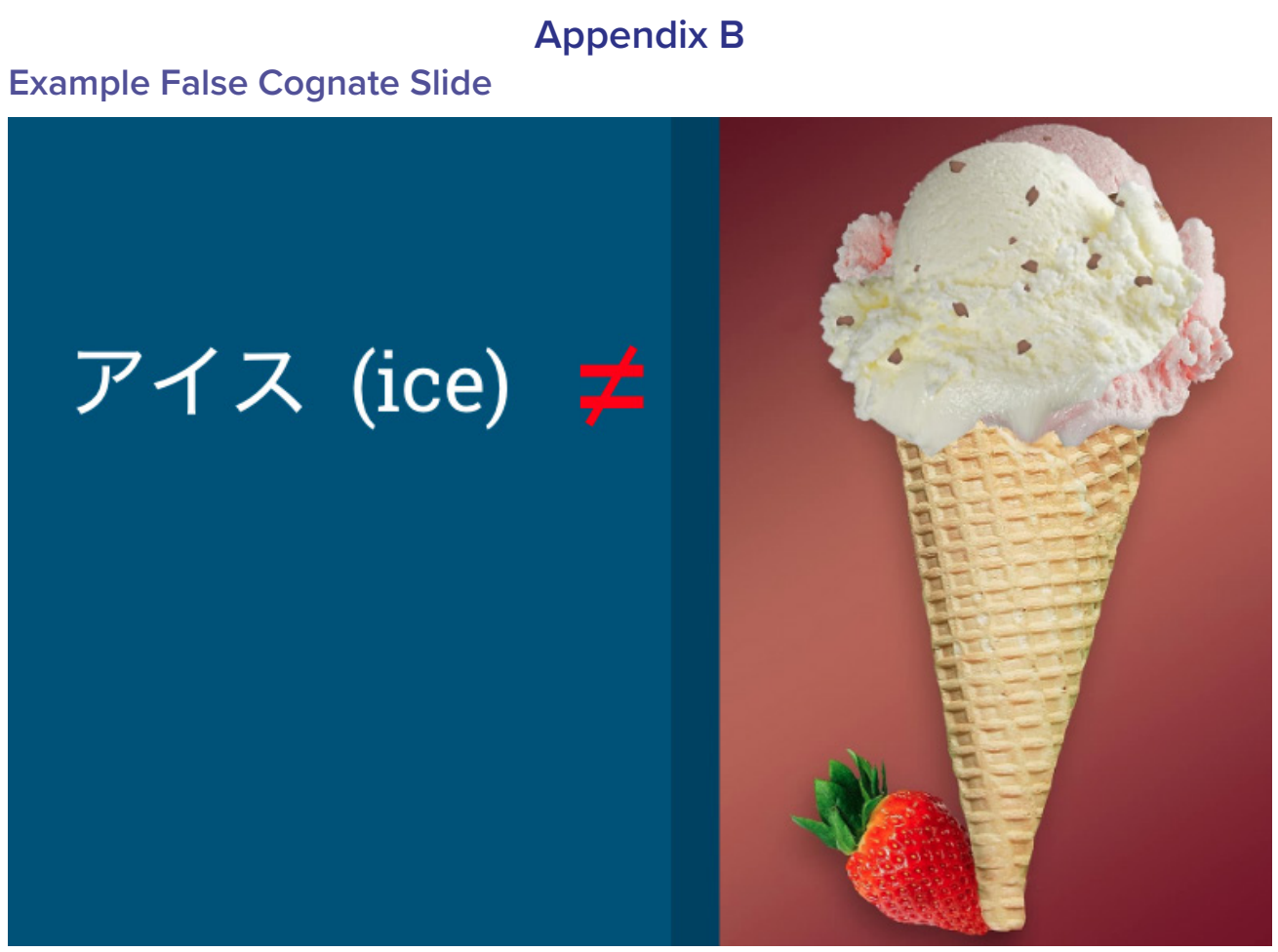

\section{Appendix B}

Garland: Gairaigo: Japanese EFL Learners' Hidden Vocabulary

\section{Gairaigo Affixes Worksheet}

These Gairaigo have all become maigo (lost children)! Help them re-unite with their families.

First, change the Gairaiigo into the English word. Then, add the correct prefix or suffix to fill in the family.

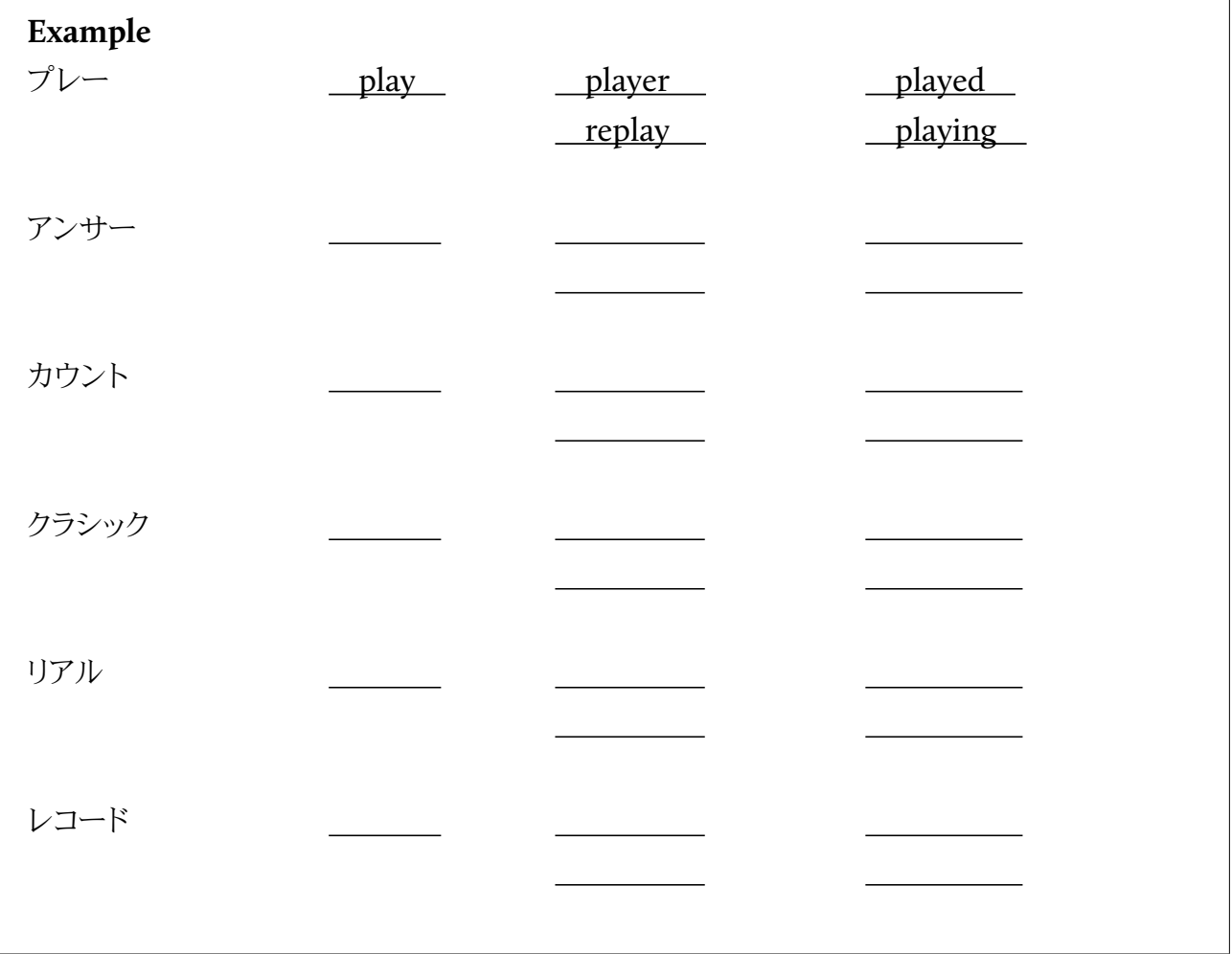

